ISSN 2712-7729 International penitentiary journal, 2020, vol. 2(1-3), iss. 3

DOI 10.33463/2712-7737.2020.02(1-3).3.182-189

Kozhokaru V. N.

Кожокару В. H.

\title{
ON THE ISSUE OF PENITENTIARY INSTITUTIONS CLASSIFICATION
}

\section{К ВОПРОСУ О КААССИФИКАЦИИ ПЕНИТЕНЦИАРНЫХ УЧРЕЖАЕНИЙ}

\begin{abstract}
The penitentiary system of the Republic of Moldova has entered a stage of reform since it was transferred from the Ministry of Internal Affairs to the Ministry of Justice. For about 20 years under the auspices of the Ministry of Justice, similar to the European penitentiary systems, the national system has been experiencing the same difficulties: a high rate of recidivism, overcrowding in places of detention, an increase in cases of detection of prohibited items and substances in penitentiary institutions, lack of staff and insufficient financial resources. The situation at the national level differs from the general European practice in terms of separate detention of persons sentenced to imprisonment. The penalty of imprisonment is executed in penitentiary institutions of the following types: open, semi-closed, for juveniles (in which conditions correspond to semi-closed penitentiary institutions) and for women, in which the regime of detention corresponds to the regime established for open, semi-closed or closed type of penitentiary institutions, depending on the category of penitentiary institutions assigned by the sentence. The rigidity of the established system is determined by the clear definition in the law of the categories of prisoners and types of penitentiary institutions for serving sentences. It is not allowed to change the type of penitentiary institution. Such a system of imprisonment execution, established by mandatory norms of criminal law, not only creates a problem for the effective implementation of criminal justice (individualization of punishment), but also determines the need to organize three modes of detention in each type of penitentiary institution. Consequently, most penitentiary institutions should have at least 12 separate detention sectors, corresponding to each type of penitentiary and detention regime. At the same time, the problem of choosing the categories of sectors that should be present in a penitentiary institution becomes very relevant. This is due to the fact that the regime of a sentence execution in the form of imprisonment in a penitentiary institution does not consist in simple isolation, but in a regime with a rich content consisting of various aspects of life and activities of convicts during execution of sentences. Based on the results of the study, the author suggests revising the content of the concept "type of penitentiary institution". This concept should include not only the

(C) Kozhokaru V. N., 2020

(C) Кожокару В. Н., 2020
\end{abstract}


ISSN 2712-7729 International penitentiary journal, 2020, vol. 2(1-3), iss. 3

level of accessibility within the penitentiary institution, but also the restrictions necessary for the detention of persons deprived of their liberty, depending on the assessment of their psychological profile, behavior and individual execution plan.

Keywords: Republic of Moldova, penitentiary institutions, regime of detention, convicts, correctional institutions, recidivism, categories of penitentiary institutions.

Аннотация. Пенитенциарная система Республики Молдова вступила в стадию реформ с момента ее передачи из ведения Министерства внутренних дел в ведение Министерства юстиции. Около 20 лет деятельности под эгидой Министерства юстиции, аналогично пенитенциарным системам Европы, национальная система претерпевает те же трудности: высокий уровень рецидива, перенасыщенность мест лишения свободы, увеличение случаев обнаружения в пенитенциарных учреждениях запрещенных предметов и веществ, нехватка персонала и недостаточность фринансовых средств. В части раздельного содержания осужденных к лишению свободы ситуация на национальном уровне отличается от общеевропейской практики. Наказание в виде лишения свободы исполняется в пенитенциарных учреждениях следующих типов: открытые, полузакрытые, закрытые, для несовершеннолетних (в которых условия содержания соответствуют полузакрытым пенитенциарным учреждениям) и для женщин, в которых режим содержания соответствует режиму, установленному для пенитенциарных учреждений открытого, полузакрытого или закрытого типа в зависимости от категории пенитенциарных учреждений, назначенных приговором. Жесткость созданной системы определяется четким закреплением в законе категорий заключенных и типов пенитенциарных учреждений для отбывания наказания. Не допускается изменение типа пенитенциарного учреждения. Такая система исполнения лишения свободы, установленная императивными нормами уголовного права, не только создает проблему для эффективной реализации уголовного правосудия (индивидуализации наказания), но и предопределяет необходимость организовывать в каждом типе пенитенциарных учреждений три режима содержания под стражей. Следовательно, в большинстве пенитенциарных учреждений должно быть не менее 12 отдельных секторов содержания под стражей, соответствующих каждому типу пенитенциарного учреждения и режиму содержания под стражей. При этом весьма актуальной становится проблема выбора категорий секторов, которые должны присутствовать в пенитенциарном учреждении. Это связано с тем, что режим исполнения наказания в виде лишения свободы в пенитенциарном учреждении заключается не в простой изоляции, а в режиме с богатым содержанием, состоящим из различных сторон жизни и деятельности осужденного во время исполнения наказания. По итогам проведенного исследования автор предлагает пересмотреть содержание понятия «тип пенитенциарного учреждения». Данное понятие должно включать в себя не только уровень доступности внутри пенитенциарного учреждения, но и ограничения, необходимые для содержания лиц, лишенных свободы, в зависимости от оценки их психологического профиля, поведения и индивидуального плана исполнения приговора.

Ключевые слова: Республика Молдова, пенитенциарные учреждения, режим содержания, осужденные, исправительные учреждения, рецидив, категории пенитенциарных учреждений. 
ISSN 2712-7729 International penitentiary journal, 2020, vol. 2(1-3), iss. 3 184 SUBJECT DISCUSSIONS / ДИскУССИИ

\section{Information about author / Сведения об авторе}

Vladimir Nikolaevich Kozhokaru, acting director, National Penitentiary Administration of the Ministry of Justice of the Republic of Moldova, Chisinau, Republic of Moldova, e-mail: vvcojocaru81@gmail.com.

Владимир Николаевич Кожокару, исполняющий обязанности директора, Национальная пенитенциарная администрация Министерства юстиции Республика Молдова, г. Кишинев, Республика Молдова, e-mail: vvcojocaru81@gmail.com.

\section{Recommended citation / Для цитирования}

Kozhokaru, V. N. 2020, 'On the issue of penitentiary institutions classification', International penitentiary journal, vol. 2(1-3), iss. 3, pp. 182-189, doi: 10.33463/27127737.2020.02(1-3).3.182-189.

Кожокару, В. Н. К вопросу о классификации пенитенциарных учреждений / В. Н. Кожокару // Международный пенитенциарный журнал. -2020. - Т. 2(1-3), № 3. C. 182-189. - DOI : 10.33463/2712-7737.2020.02(1-3).3.182-189. 
The penitentiary system of the Republic of Moldova has entered a stage of reform since it was transferred from the Ministry of Internal Affairs to the Ministry of Justice. For about 20 years under the auspices of the Ministry of Justice, similar to the European penitentiary systems, the national system has been experiencing the same difficulties: a high rate of recidivism, overcrowding in places of detention, an increase in cases of detection of prohibited items and substances in penitentiary institutions, lack of staff and insufficient financial resources. Unlike other developed penitentiary systems that adopted a modern approach to the execution of custodial sentences in the sixth decade of the last century, the penitentiary system of the Republic of Moldova has to gradually adapt at an accelerated pace to European norms and standards. These standards contain an exhaustive list of principles, the implementation of which seems to be within the power of each state, regardless of its material capabilities.

Thus, we pay special attention to the current actions and the goals that we intend to implement, in terms of two main issues: 1) why we punish; 2) how people get out of prison. For this reason, the main task of the penitentiary system is to respect the rights and freedoms of persons deprived of their liberty in order to facilitate their social reintegration. At present, the system of administration of penitentiary institutions consists of the National administration of penitentiary institutions, 17 penitentiary institutions, 2 specialized institutions (a training center and a special purpose unit). Persons deprived of their liberty are placed in:

- closed-type penitentiary institutions (11 institutions, 4 of them with the status of a criminal investigation detention center);

- semi-closed penitentiary institutions (3 institutions);

- female colony;

- juvenile penitentiary institutions;

- penitentiary hospitals.
The current regulatory framework allows for the creation of several separate detention areas in a penitentiary institution in accordance with the features provided for by the Executive Code of the Republic of Moldova No. 433-XV of 24.12.2004 (the EC of the RM). The execution of imprisonment requires the creation of an internal structure of pre-trial detention facilities in order to offer the administration of the place of detention real opportunities for separate detention of persons in accordance with the criteria established by the penal legislation. Such criteria are set out in Articles 205 and 304 of the EC of the RM the following convicted persons are kept separately in penitentiary institutions:

a) women from men;

b) minors from adults;

c) persons held under provisional arrest from convicted persons;

d) convicted persons for the first time from convicted persons who previously served a sentence of imprisonment and have an outstanding criminal record;

e) convicts sentenced to life imprisonment from the rest of the convicts;

f) persons convicted for complicity in the commission of a crime from accomplices;

g) convicts transferred to the initial regime of detention in the order of disciplinary punishment, from convicted persons who are initially on the initial regime;

h) convicts who may face reprisals because of their previous position, from other convicts;

i) convicts who use the right to move without a convoy or escort, from other convicts.

In addition to the criteria for pre-trial detention, the following criteria for separation are established:

a) persons who were first placed in pre-trial detention, from persons who were previously held in penitentiary institutions;

b) persons suspected or accused of committing serious, especially serious and extremely serious crimes, from other persons;

c) persons, who held responsible positions in public authorities before being taken into custody, from other persons; 
ISSN 2712-7729 International penitentiary journal, 2020, vol. 2(1-3), iss. 3 186

d) persons, suffering from infectious diseases or requiring special medical care and supervision, from other persons;

Persons, who are left in criminal detention centers for economic maintenance work in accordance with the procedure established by law, are kept in separate premises isolated from persons under preliminary arrest.

In order to improve the safety of prisoners or create conditions for their treatment, the administration of a penitentiary institution may apply other criteria for the separation of prisoners (article 205, paragraph 2, of the $E C$ of the RM). In addition, the separation of prisoners in a correctional facility should not be discriminatory or infringe on human dignity. Thus, the separation of convicts is also regulated at the level of internal legal acts of the National penitentiary administration by establishing additional criteria for organizing the execution of a custodial sentence for protection of:

- certain categories of detainees;

- mother with child;

- detainees suffering from severe mental disorders, including those caused by the use of alcohol or psychotropic substances;

- persons on probation, etc.

The task of placing them in pre-trial detention facilities according to the specified criteria is difficult, including in connection with the current system of distribution of persons for the execution of sentences by type of penitentiary institution and the regime of detention.

Thus, the situation at the National level differs from the general European practice. According to Article 72 of the Criminal Code of the Republic of Moldova (the CC of the RM), the penalty of imprisonment is applied in the following types of penitentiary institutions: open, semi-closed, for juveniles (in which the conditions of detention arising from the provisions of Article 273 of the EC of the $\mathrm{RM}$, correspond to semi-closed penitentiary institutions) and for women, which according to Article 276 of the EC of the RM the regime of detention corresponds to the regime established for open, semi-closed or closed penitentiary institutions, depending on the category of penitentiary institutions assigned by the sentence.

The rigidity of the established system is determined by the clear definition in the law of the categories of prisoners and types of penitentiary institutions for serving sentences. It is not allowed to apply sanctions to detainees by transferring them from one type of penitentiary institution to another. Thus, article 72 OF the CU of the RM provides that:

- persons sentenced to imprisonment for crimes committed by negligence serve their sentences in open-type penitentiary institutions;

- persons sentenced to imprisonment for minor crimes, medium-gravity crimes and serious crimes committed intentionally serve their sentences in semi-closed penitentiary institutions;

- persons sentenced to imprisonment for especially serious and extremely serious crimes, as well as persons who have committed crimes that constitute a recidivism, serve their sentences in closed-type penitentiary institutions.

The norm concerning the establishment of the type of penitentiary institution under sentence does not contribute to the individualization of punishment, does not take into account such circumstances as the personality of the convicted person, his financial situation, etc., since when determining the gravity of the crime and the type of guilt, the convicted person can be automatically sent to the appropriate penitentiary institution without the need to mention this in the sentence. The main problem arising from the system of sentences execution is that it is impossible to change the type of correctional institution even through the courts, although there is a rule contained in Paragraph 7 of Article 72 of the $\mathrm{CC}$ of the RM, according to which the type of penitentiary institution is changed by the court in accordance with the law. In practice, this rule can only be applied if the person was convicted again during the sentence execution for another 
more serious act, for which the law provides for the sentence execution in a penitentiary institution of a more severe category (type). Thus, there is a need to place convicted persons for their sentence execution in the appropriate regimes. Under the term "appropriate regime" we understand the specific form of application of the penitentiary regime, taking into account the division of detainees into compartments and cells, categories of crimes, the nature of their commission, terms of punishment, the state of recidivism, social and public danger, age and gender (Petrake, Z. 1992, p 25).

The system of imprisonment execution established by mandatory norms of criminal law not only creates a problem for the effective implementation of criminal justice (individualization of punishment), but also determines the need to organize three regimes of detention in each type of penitentiary institution. For penitentiary institutions, this is a big practical problem in terms of creating the conditions established by law and observing the restrictions specific to a particular type of penitentiary institution, in which a person must serve a sentence under a court decision. The specifics of each regime are presented in table 1. Thus, we observe a situation where in most penitentiary institutions, in accordance with the order of the Ministry of justice No. 189/2017 on the establishment of the type of penitentiary institution and its sectors, there must be at least 12 separate detention sectors corresponding to each type of penitentiary institution and detention regime.

Clarification of the conditions under which a person deprived of liberty will serve his sentence is also necessary, because the prison environment also contributes to the emergence of deviant behavior among convicts. Therefore, in order to regulate situations caused by deviant behavior, it is important that the teacher knows as well as possible the stages of the educational process, the features characteristic of the environment that counteracts the work on reeducation and resocialization of convicts. At the first stage of detention, there are phenomena of mental agitation, anxiety, lack of appetite for the received food, etc. (symptoms of the psychology of detention). In the second stage, the prisoner begins to feel deeply the influence of the prison due to the significant restriction of movement space and time organization, which leads to a tendency to protect their territory. At the third stage, the convict is disappointed because of the organization of time established by internal rules. The time spent in prison is monotonous, which can lead to increased aggression of the convict. In the fourth phase, when certain items are provided for personal use in accordance with internal rules, the feeling of frustration increases. In the fifth phase, contact with the prison subculture has serious consequences. Because of the environment in which the convict is forced to spend his incarceration, a new vision of himself is formed, and at the same time he is forced to form a "survival strategy" to help himself cope with difficulties that he did not face in freedom (Florian, I. 2002, p.211).

Thus, we are faced with the conceptual problem of choosing the categories of sectors (sections) that should be present in a penitentiary institution. This is due to the fact that the regime of a sentence execution in the form of imprisonment in a correctional institution is not a simple isolation, but a regime with a rich content consisting of various aspects of the life and activities of the convict during the execution of the sentence in a penitentiary institution (Ion, O. 1998, p. 86).

In connection with the above, it is necessary to revise the content of the concept "type of penitentiary institution". When we talk about closed, semi-closed and open penitentiary institutions, we must take into account not only the level of accessibility within the penitentiary institution, but also the restrictions necessary for the detention of persons deprived of their liberty, depending on the assessment of their psychological profile and behavior, and the individual execution plan. Penitentiary institutions should have separate premises (sectors) for persons deprived of their liberty, 
ISSN 2712-7729 International penitentiary journal, 2020, vol. 2(1-3), iss. 3 188

SUBJECT DISCUSSIONS / ДИскУсСИИ

\begin{tabular}{|c|c|c|c|c|c|c|c|c|c|c|c|c|}
\hline 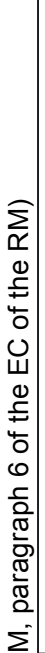 & 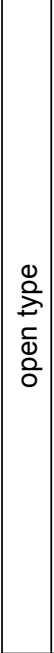 & 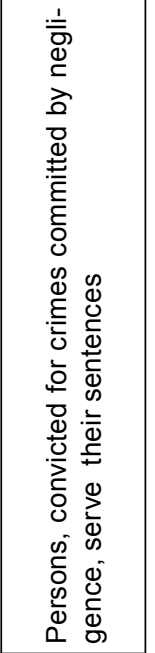 & 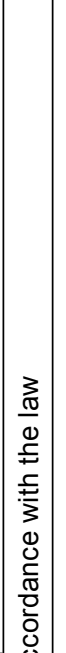 & & 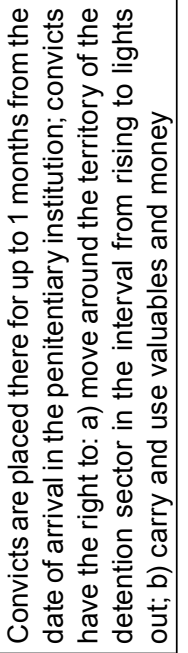 & & 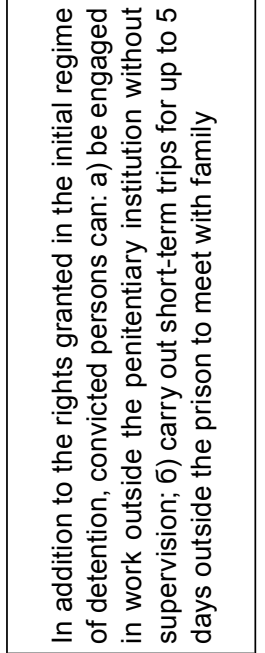 & & 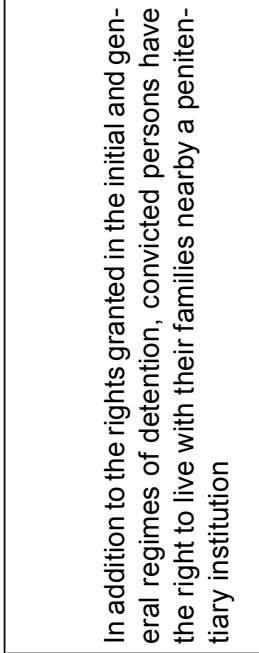 & & & 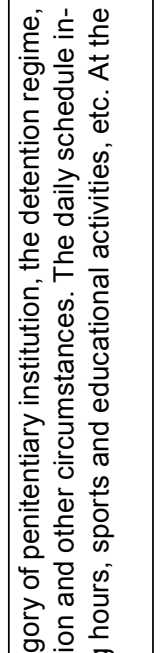 \\
\hline 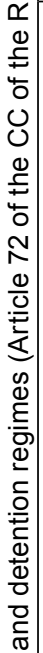 & 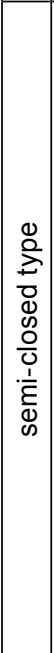 & 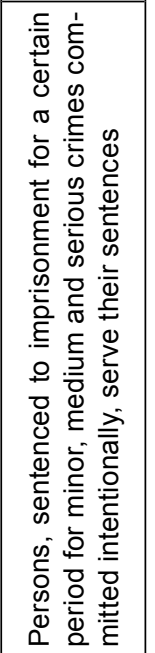 & 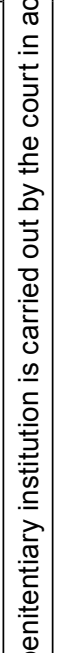 & 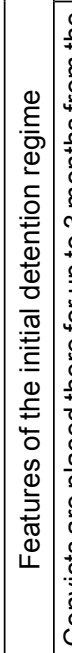 & 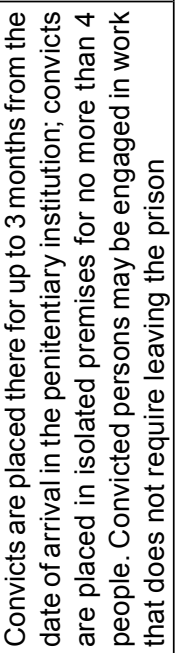 & 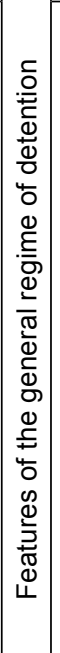 & 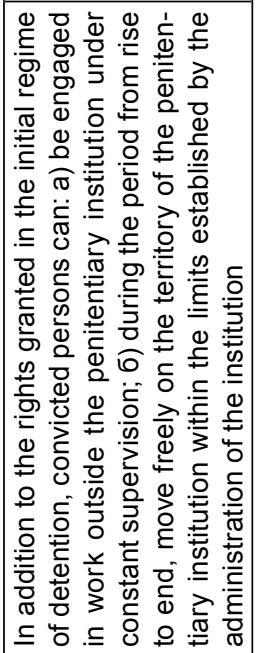 & 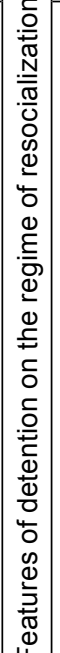 & 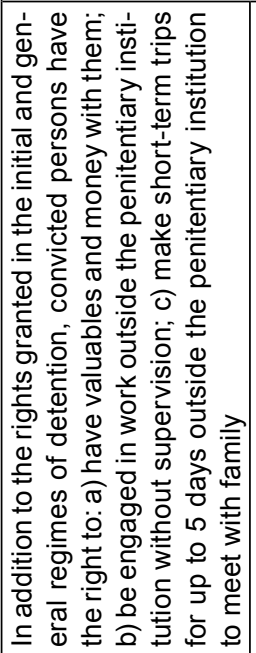 & 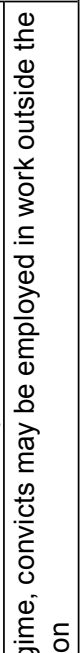 & 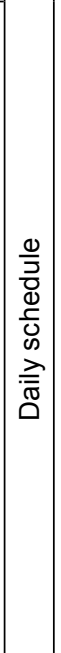 & 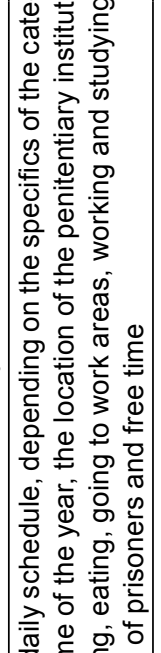 \\
\hline 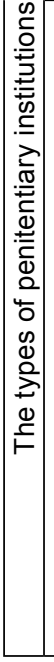 & $\mid \begin{array}{l}0 \\
0 \\
2 \\
0 \\
0 \\
0 \\
0 \\
0 \\
0 \\
0\end{array}$ & 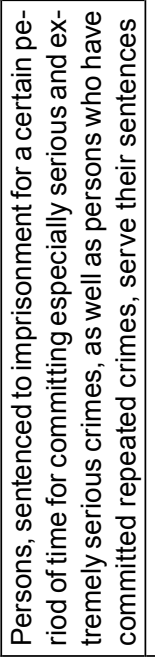 & 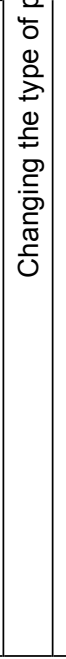 & & 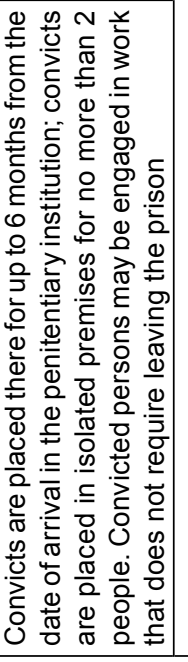 & & 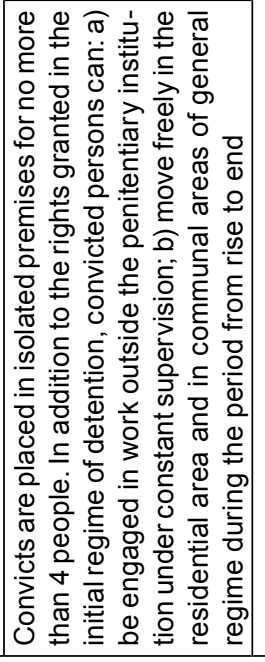 & & 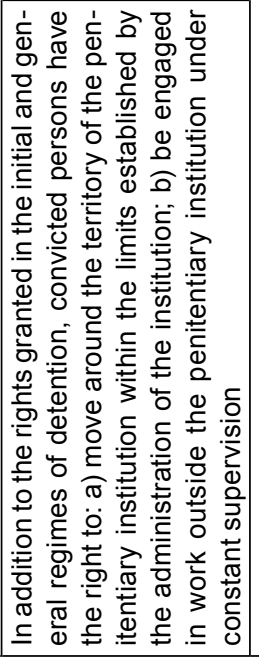 & 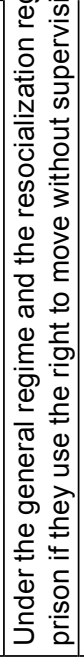 & & 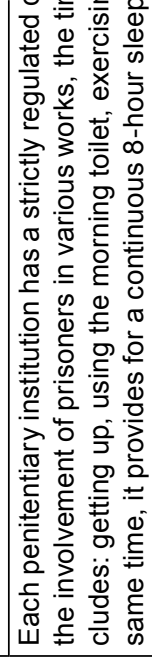 \\
\hline
\end{tabular}


ISSN 2712-7729 International penitentiary journal, 2020, vol. 2(1-3), iss. 3

in accordance with their procedural situation, the level of danger they pose to themselves and others, as well as the conditions established by the individual detention plan (Barbu, G. S. \& Shtefan, A. 2005, p. 94). Thus, depending on the profile of convicts, penitentiary institutions should have separate sections that allow them to move between sectors, depending on the level of implementation of the goals set out in the execution plan. The right to make a decision on changing one regime to another should be given to the administration of the place of detention.

The penitentiary system plays an important role in the execution of custodial sentences. The nature of the penitentiary regime depends on achieving the goal of executing the sentence of imprisonment, reeducating the convicted person and deterring him from committing a new crime. We can say that the penitentiary system defines how the execution of a sentence of imprisonment in a penal institution or as organized life and activities of a convict in the penitentiary institution during the execution of the punishment for the purpose of reeducation and prevention of new crimes and offences. (Trayan, P. 1924, p. 98).

\section{References}

Petrake, Z. 1992, Penitentiary system in Romania, Police Academy "Alexandru Ioan Cuza", Bucharest.

Florian, I. 2002, Criminology and penitentiary science.

Ion, O. 1998, Penal law, All Educational Publishing House.

Barbu, G. S. \& Shtefan, A. 2005, Criminal law, Bucharest.

Trayan, P. 1924, Comparative criminal law, penology and penitentiary science, Cluj.

\section{Библиографический список}

Петраке 3. Пенитенциарная система в Румынии : монографрия. Бухарест : Полицейская Академия «Alexandru loan Cuza», 1992.

Флориан И. Криминология и пенитенциарная наука. 2002.

Ион О. Уголовно-исполнительное право. All Educational Publishing House, 1998.

Барбу Г. С., Штефран А. Уголовное право. Бухарест, 2005.

Траян П. Сравнительное уголовное право, пенология и пенитенциарная наука. Клуж, 1924. 